\title{
Perinatal outcomes of singleton term breech deliveries in Basra
}

\author{
H. Alshaheen ${ }^{7}$ and A. Abd Al-Karim ${ }^{2}$
}

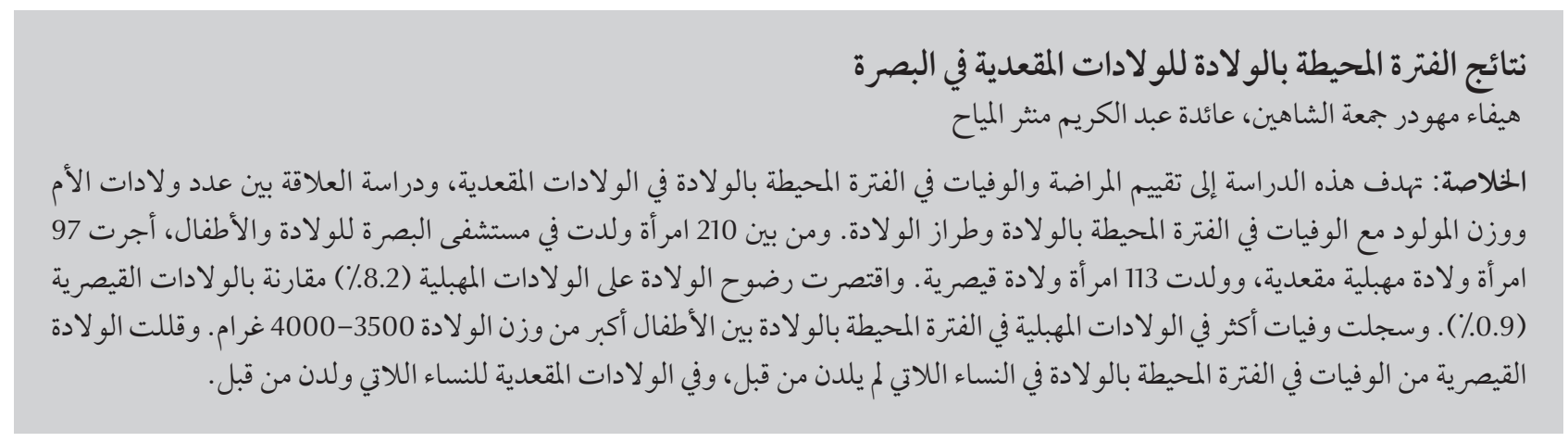

ABSTRACT This study aimed to assess the perinatal morbidity and mortality in breech deliveries, to study the correlation of parity and birth weight with perinatal mortality by mode of delivery. Of 210 women in labour in Basra maternity and child hospital, 97 underwent vaginal breech deliveries and 113 delivered by caesarean section. Birth trauma was restricted to vaginal deliveries. The perinatal mortality was significantly higher in vaginal deliveries (8.2\%) compared with caesarean deliveries (0.9\%). A higher perinatal mortality was recorded among infants $>3500-4000 \mathrm{~g}$ birth weight in vaginal deliveries. Caesarean section reduced the perinatal mortality in both nulliparous and parous women in term breech infants.

\section{Issue périnatale d'accouchements par le siège d'enfants uniques nés à terme à Bassora (Iraq)}

RÉSUMÉ Cette étude visait à évaluer la morbidité et la mortalité périnatales associées aux accouchements par le siège afin d'étudier la corrélation entre d'une part, le nombre d'enfants nés vivants et le poids à la naissance et d'autre part, la mortalité périnatale selon le type d'accouchement. Sur 210 femmes en travail à la maternité-hôpital pour enfants de Bassora, 97 ont eu un accouchement par voie basse par le siège et 113 ont accouché par césarienne. Les traumatismes obstétricaux étaient limités aux accouchements par voie basse. La mortalité périnatale était significativement plus élevée pour les accouchements par voie basse (8,2\%) que pour les accouchements par césarienne (0,9\%). Une mortalité périnatale plus élevée a été enregistrée chez les nourrissons nés par voie basse et pesant plus de 3,5 kg à 4 kg à la naissance. La césarienne réduisait la mortalité périnatale des nourrissons nés à terme par le siège chez les femmes nullipares et multipares. 


\section{Introduction}

It has long been thought that vaginal delivery of breech infants is associated with increased neonatal morbidity and mortality compared with elective caesarean delivery [1]. This observation has been a topic of considerable debate over the past few years, and retrospective studies of the subject have yielded conflicting data [2-6]. The frequency of breech presentation is approximately $3 \%$ of term all term deliveries, according to a large population-based study in the United States [7]. The controversy over appropriate management of breech presentation, as well as considerable disagreement regarding appropriate candidates for a trial of vaginal breech delivery, has made it a difficult phenomenon to study prospectively.

Only 3 prospective, randomized controlled studies have examined maternal and newborn outcomes associated with breech vaginal delivery $[8-10]$. The first 2 were published more than 20 years ago and found minimal increased risk to the fetus in a carefully selected group of vaginal breech deliveries $[8,9]$. In these 2 older studies, however, maternal morbidity was significantly increased (49\%) with caesarean delivery, thus influencing decisions to undergo a trial of labour for breech presentation $[8,9]$. More recently, in the Term Breech Trial, Hannah et al. conducted a large, multicentre, prospective, randomized controlled trial of vaginal breech delivery as compared with planned caesarean delivery [10]. They found a lower rate of perinatal and neonatal mortality and serious neonatal morbidity (1.6\% for planned caesarean delivery compared with 5.0\% in planned vaginal birth) with no significant differences in maternal morbidity or mortality. This study prompted the American College of Obstetricians and Gynecologists to recommend planned caesarean delivery for term singleton breech presentation [11]. Some workers, however, have argued that the design of the Term Breech Trial is flawed, and the debate continues [12].

The aim of this study was to assess the perinatal outcome in singleton term infants delivered in breech presentation in Basra maternity and child hospital and to study the correlation of parity and birth weight with perinatal mortality by mode of delivery.

\section{Methods}

This prospective study was conducted over a 12-month period (from 1 September 2005 to 31 August 2006) on women attending the delivery room with a live singleton term breech presentation at the maternity and child hospital in Basra, Iraq. Of the 10215 deliveries during the study period, 259 were breech presentation. Only women who delivered during the researchers' visits (3-4 times per week) were included in the study $(n=210)$. Women with obstetric problems and medical illnesses were excluded from the study.

All women were examined by the same obstetrician, and medical and neonatal data were obtained, including maternal age, parity, educational level, date of last menstrual period, previous caesarean section, previous admission to neonatal intensive care unit (NICU), history of infertility and maternal illnesses. All women were informed about the study before they gave consent to participate. All of the women who were eligible for the study consented to participate.

Abdominal examination was performed for fetal presentation, engagement and fetal size. Pelvic examination was performed under full aseptic techniques, to assess cervical dilatation, type of breech and state of amniotic membranes, to exclude cord prolapse or presentation and to assess the pelvis. Ultrasound was done to confirm gestational age, estimate fetal weight, exclude congenital malformations of the fetus, exclude twin pregnancy and locate the placenta. Abdominal X-ray was performed only to women who were in the early stages of labour $(n=$ 156) to diagnose extended head. This was standard practice in our hospital.

All women chose trial of labour, no woman requested caesarean section. When caesarean section was performed it was clinically indicated by the judgement of the attending obstetricians and after discussion with the patient. A trial of breech vaginal delivery was done only for those patients who had the inclusion criteria for breech vaginal delivery. Those who did not meet these criteria delivered by caesarean section without trial of labour.

The inclusion criteria for a trial breech delivery were: a clinically adequate pelvis, a frank or complete breech with estimated fetal weight $<4 \mathrm{~kg}$ with a flexed head and the informed consent of the mother. Labour was allowed to progress and the fetal heart rate was continuously monitored by electronic fetal heart monitoring with regular abdominal and pelvic examination. The method of delivery was assisted or spontaneous breech delivery by the most experienced obstetrician. Conversion to caesarean section was considered appropriate whenever the need arose, e.g. lack of progress of labour and fetal distress. The indications for caesarean section were: primigravida aged $>35$ years, conception after infertility, previous difficult vaginal delivery, macrosomia, cephalopelvic disproportion and breech with footling presentation.

All neonates were examined following delivery by the paediatric resident. Body weight was recorded and gestational age was assessed using Dubowitz criteria [13]. Perinatal outcome was assessed including Apgar scores at 1 minute and 5 minutes, admissions to NICU, as well as birth traumas and deaths. 
The overall perinatal mortality rate was calculated according to the formula: [no. of still births + no. of 1st-week neonatal deaths)/no. of total births] $\times$ 100. Perinatal mortality in relation to parity and birth weight were compared by route of delivery.

Statistical analysis was done using the chi-squared test, with $P$-value $<0.05$ considered to be significant. It was not used in samples of less than 5 .

\section{Results}

A total of 210 women were included in this study, 97 (46.2\%) who delivered vaginally and $113(53.8 \%)$ who had an emergency caesarean section.

The maternal and birth characteristics of the women are presented in Table 1. There were 104 nulliparas and 106 paras. There were statistically significant differences in the age and parity of women who delivered vaginally and those who delivered by caesarean section. There was higher incidence of caesarean deliveries among the nulliparous group $(P<0.05)$. A significantly higher percentage of caesarean deliveries were among well-educated women $(P<$ $0.05)$. There was a significant difference in infant's birth weight between the 2 groups, with a higher rate of caesarean deliveries among women who gave birth to infants weighing 3500-4000 g.

Neonates of vaginal deliveries had a higher incidence of Apgar score $<7$ at 1 and 5 minutes (both $P<0.05$ ). NICU admittance was significantly higher in the vaginal compared with the caesarean delivery group $(P<0.05)$ (Table $2)$. All the cases of birth trauma were in vaginally-delivered infants. There were 3 (3.1\%) infants with brachial plexus lesion, 2 (2.1\%) with birth asphyxia and $1(1.0 \%)$ with a fractured clavicle (Table 3).

The overall perinatal mortality rate was $4.3 \%$ (9/210). Neonatal deaths in the first week occurred significantly

\begin{tabular}{|c|c|c|c|c|c|c|c|}
\hline \multirow[t]{2}{*}{ Maternal factors } & \multicolumn{2}{|c|}{$\begin{array}{c}\text { Vaginal delivery } \\
\qquad(\boldsymbol{n}=97)\end{array}$} & \multicolumn{2}{|c|}{$\begin{array}{c}\text { Caesarean } \\
\text { section } \\
(n=113)\end{array}$} & \multicolumn{2}{|c|}{$\begin{array}{c}\text { Total } \\
(n=210)\end{array}$} & \multirow[t]{2}{*}{$P$-value } \\
\hline & No. & $\%$ & No. & $\%$ & No. & $\%$ & \\
\hline \multicolumn{8}{|l|}{ Age (years) } \\
\hline $17-30$ & 50 & 51.5 & 74 & 65.5 & 124 & 59.0 & \multirow[t]{2}{*}{$<0.01$} \\
\hline $31-45$ & 47 & 48.5 & 39 & 34.5 & 86 & 41.0 & \\
\hline \multicolumn{8}{|l|}{ Parity } \\
\hline Nulliparous & 21 & 21.6 & 83 & 73.5 & 104 & 49.5 & \multirow[t]{2}{*}{$<0.01$} \\
\hline Parous & 76 & 78.4 & 30 & 26.5 & 106 & 50.5 & \\
\hline \multicolumn{8}{|l|}{ Educational level } \\
\hline Illiterate & 40 & 41.2 & 20 & 17.7 & 60 & 28.6 & \multirow[t]{4}{*}{$<0.01$} \\
\hline Primary & 37 & 38.0 & 29 & 25.7 & 66 & 31.4 & \\
\hline Secondary & 15 & 15.5 & 54 & 47.8 & 69 & 33.0 & \\
\hline Higher & 5 & 5.2 & 10 & 8.8 & 15 & 7.0 & \\
\hline \multicolumn{8}{|l|}{ Occupation } \\
\hline Housewife & 87 & 89.7 & 93 & 82.3 & 180 & 85.7 & \multirow[t]{2}{*}{$>0.05$} \\
\hline Employed & 10 & 10.3 & 20 & 17.7 & 30 & 14.3 & \\
\hline \multicolumn{8}{|c|}{ Infant's birth weight (g) } \\
\hline $2500-3500$ & 81 & 83.5 & 82 & 72.6 & 163 & 77.6 & \multirow[t]{2}{*}{$<0.01$} \\
\hline$>3500-4000$ & 16 & 16.5 & 31 & 27.4 & 47 & 22.4 & \\
\hline
\end{tabular}

$n=$ number of women/births.

\begin{tabular}{|c|c|c|c|c|c|c|c|}
\hline \multicolumn{8}{|c|}{$\begin{array}{l}\text { Table } 2 \text { Apgar scores and neonatal intensive care unit (NICU) admittance by mode } \\
\text { of delivery }\end{array}$} \\
\hline \multirow[t]{2}{*}{ Variable } & \multicolumn{2}{|c|}{$\begin{array}{c}\text { Vaginal } \\
\text { delivery } \\
(n=97)\end{array}$} & \multicolumn{2}{|c|}{$\begin{array}{c}\text { Caesarean } \\
\text { section } \\
(n=113)\end{array}$} & \multicolumn{2}{|c|}{$\begin{array}{l}\text { Total } \\
(n=210)\end{array}$} & \multirow[t]{2}{*}{$P$-value } \\
\hline & $\%$ & No. & $\%$ & No. & $\%$ & No. & \\
\hline Apgar score $<7$ at $1 \mathrm{~min}$ & 10 & 10.3 & 3 & 2.7 & 13 & 6.2 & $<0.05$ \\
\hline Apgar score $<7$ at 5 min & 10 & 10.3 & 2 & 1.8 & 12 & 5.7 & $<0.05$ \\
\hline NICU admittance & 8 & 8.2 & 2 & 1.8 & 10 & 4.8 & $<0.05$ \\
\hline
\end{tabular}

\begin{tabular}{lcccc}
\hline $\begin{array}{l}\text { Table } 3 \text { Fetal morbidity by mode of delivery } \\
\text { Variable }\end{array}$ & \multicolumn{2}{c}{$\begin{array}{l}\text { Vaginal delivery } \\
(\boldsymbol{n}=\mathbf{9 7})\end{array}$} & \multicolumn{2}{c}{$\begin{array}{c}\text { Caesarean section } \\
(\boldsymbol{n}=\mathbf{1 1 3})\end{array}$} \\
No. & $\%$ & No. & $\%$ \\
Brachial plexus lesion & 3 & 3.1 & 0 & - \\
Birth asphyxia & 2 & 2.1 & 0 & - \\
Fracture clavicle & 1 & 1.0 & 0 & - \\
Meconium aspiration & 0 & - & 1 & 0.9 \\
Total & 6 & 6.2 & 1 & 0.9 \\
\hline
\end{tabular}

more often among infants delivered vaginally $(8 / 97,8.2 \%)$ than by with caesarean delivery $(1 / 113,0.9 \%)$ $(P<0.05)$. There were no stillbirths in either group (Table 4). The cause of 1st-week neonatal death was birth asphyxia in both vaginal and caesarean deliveries.

Neonatal mortality was higher in both nulliparous and parous women 


\begin{tabular}{|c|c|c|c|c|c|c|c|}
\hline \multirow[t]{2}{*}{ Variable } & \multicolumn{2}{|c|}{$\begin{array}{l}\text { Vaginal delivery } \\
\qquad(\boldsymbol{n}=97)\end{array}$} & \multicolumn{2}{|c|}{$\begin{array}{c}\text { Caesarean section } \\
\qquad(n=113)\end{array}$} & \multicolumn{2}{|c|}{$\begin{array}{c}\text { Total } \\
(n=210)\end{array}$} & \multirow[t]{2}{*}{$P$-value } \\
\hline & No. & $\%$ & No. & $\%$ & No. & $\%$ & \\
\hline Stillbirths & 0 & - & 0 & - & 0 & - & - \\
\hline $\begin{array}{l}\text { 1st-week neonatal } \\
\text { deaths }\end{array}$ & 8 & 8.2 & 1 & 0.9 & 9 & 4.3 & $<0.05$ \\
\hline $\begin{array}{l}\text { Overall perinatal } \\
\text { deaths }\end{array}$ & 8 & 8.2 & 1 & 0.9 & 9 & 4.3 & $<0.05$ \\
\hline
\end{tabular}

when comparing vaginal and caesarean deliveries (Table 5). Among the nulliparas, a higher rate of neonatal mortality was recorded for vaginal deliveries (23.8\%) compared with caesarean deliveries (1.2\%). For the paras, there were $3 / 76$ neonatal deaths in the vaginal delivery group (3.9\%) while there were no neonatal deaths in the caesarean delivery group. Among the infants with birth weight $2500-3500 \mathrm{~g}$, there were 6 neonatal deaths $(7.4 \%)$ for those delivered vaginally while there were no neonatal deaths among caesarean deliveries (Table 6). In the infants with birth weight $3500-4000 \mathrm{~g}$, the neonatal death rate was $12.5 \%$ for vaginal deliveries and $3.2 \%$ for those delivered by caesarean.

\section{Discussion}

According to Cheng and Hannah who reviewed 24 studies in 1993, vaginal delivery is associated with higher perinatal morbidity and mortality rates than planned caesarean delivery [14]. They suggested that, until more evidence was available, a planned caesarean delivery should be strongly considered for persistent breech presentation at term. A study by Bingham et al. concluded that a

\begin{tabular}{|c|c|c|c|c|c|c|c|c|}
\hline \multirow[t]{3}{*}{ Variable } & \multicolumn{4}{|c|}{ Nulliparous } & \multicolumn{4}{|c|}{ Parous } \\
\hline & \multicolumn{2}{|c|}{$\begin{array}{c}\text { Vaginal } \\
\text { delivery } \\
(n=21)\end{array}$} & \multicolumn{2}{|c|}{$\begin{array}{c}\text { Caesarean } \\
\text { section } \\
(n=83)\end{array}$} & \multicolumn{2}{|c|}{$\begin{array}{l}\text { Vaginal } \\
\text { delivery } \\
(n=76)\end{array}$} & \multicolumn{2}{|c|}{$\begin{array}{c}\text { Caesarean } \\
\text { section } \\
(n=30)\end{array}$} \\
\hline & No. & $\%$ & No. & $\%$ & No. & $\%$ & No. & $\%$ \\
\hline Stillbirths & 0 & - & 0 & - & 0 & - & 0 & - \\
\hline $\begin{array}{l}1^{\text {st }} \text {-week neonatal } \\
\text { deaths }\end{array}$ & 5 & 23.8 & 1 & 1.2 & 3 & 3.9 & 0 & - \\
\hline $\begin{array}{l}\text { Overall perinatal } \\
\text { deaths }\end{array}$ & 5 & 23.8 & 1 & 1.2 & 3 & 3.9 & 0 & - \\
\hline
\end{tabular}

\begin{tabular}{|c|c|c|c|c|c|c|c|c|}
\hline \multirow[t]{3}{*}{ Variable } & \multicolumn{4}{|c|}{ Birth weight $2500-3500 \mathrm{~g}$} & \multicolumn{4}{|c|}{ Birth weight $3500-4000 \mathrm{~g}$} \\
\hline & \multicolumn{2}{|c|}{$\begin{array}{r}\text { Vaginal } \\
\text { delivery } \\
(n=81)\end{array}$} & \multicolumn{2}{|c|}{$\begin{array}{c}\text { Caesarean } \\
\text { section } \\
(\boldsymbol{n}=\mathbf{8 2})\end{array}$} & \multicolumn{2}{|c|}{$\begin{array}{c}\text { Vaginal } \\
\text { delivery } \\
(n=16)\end{array}$} & \multicolumn{2}{|c|}{$\begin{array}{c}\text { Caesarean } \\
\text { section } \\
(n=31)\end{array}$} \\
\hline & No. & $\%$ & No. & $\%$ & No. & $\%$ & No. & $\%$ \\
\hline Stillbirths & 0 & - & 0 & - & 0 & - & 0 & - \\
\hline $\begin{array}{l}\text { 1st-week neonatal } \\
\text { deaths }\end{array}$ & 6 & 7.4 & 0 & - & 2 & 12.5 & 1 & 3.2 \\
\hline $\begin{array}{l}\text { Overall perinatal } \\
\text { deaths }\end{array}$ & 6 & 7.4 & 0 & - & 2 & 12.5 & 1 & 3.2 \\
\hline
\end{tabular}

policy of selected vaginal delivery will result in 4 perinatal deaths for every 1000 patients delivered [15]. Other studies suggested a potential increased risk of neonatal morbidity and mortality after a trial of labour and vaginal delivery and that there was greater neonatal survival in association with caesarean section [16-18].

Although there is a growing tendency worldwide to perform elective caesarean section for infants presenting in the breech position, a trial of vaginal delivery is still allowed in selected breech cases in our main maternity centre in Basra. In this prospective study the perinatal outcomes of 113 women delivered by emergency caesarean section were compared with those of 97 women delivered vaginally. We found that, even applying appropriate inclusion criteria for a trial of labour, vaginal breech deliveries seemed to be associated with significantly greater neonatal risks. The overall neonatal outcomes were better in the caesarean section group compared with the vaginal delivery group.

In this study, the rate of caesarean section for term breech presentation was $53.8 \%$; this finding is lower than that reported by Diro et al. [19]. Maternal educational level was inversely proportional to the rate of vaginal breech birth. This study has confirmed that illiterate women were more likely to deliver a breech infant vaginally than were educated women. This finding is similar to that of Gilbert et al. [1]. This may indicate that illiterate women have inadequate information about the adverse perinatal outcome of vaginal breech delivery due to inadequate or no antenatal care. Mothers who were better educated were more likely to have caesarean section for their breech birth. It should be noted that caesarean section was clinically indicated and not on the patient's request. This can be explained by better educated women having adequate antenatal care and 
being assigned to planned caesarean section by their obstetrician. Therefore, when labour started earlier with persistent breech, the caesarean section was performed immediately on admission.

Parity and birth weight were also evaluated. There were more nulliparas in the caesarean section (73.5\%) than the vaginal delivery $(21.6 \%)$ group, which is similar to the results of Gilbert et al. [1]. Birth weight is an important factor affecting the caesarean section rate in breech delivery, with more infants weighing > 3500-4000 $\mathrm{g}$ in the caesarean section (27.4\%) than vaginal delivery (16.5\%) groups in our study. This finding is in agreement with the studies of Doyle et al. and Koo et al. $[20,21]$.

The present study confirmed that Apgar score $<7$ at 5 minutes occurred significantly more often among vaginal deliveries. This finding is in contrast to that of Doyle et al. [20]. Also, our study documented a significantly higher rate in NICU admission for vaginal breech deliveries ( $8.2 \%$ versus $1.8 \%)$. This rate is lower than that of Koo et al. which may be due to the large sample in their study [21].

Our results indicate that major neonatal morbidity was increased with vaginal breech deliveries. The most striking was risk of brachial plexus injury; this was a major cause of injury associated with breech vaginal deliveries in our study (3.1\%). This is in agreement to that reported by Collea et al. who found that $3.3 \%$ of births with brachial plexus injury in the vaginal delivery group [8]. Clearly our study supports the view that vaginal breech delivery is associated with birth trauma more often than caesarean deliveries [22].

When comparing vaginal and caesarean deliveries, the present study has confirmed a significant association between mode of delivery and neonatal mortality. A significantly higher neonatal death was reported among vaginal breech deliveries. Our neonatal mortality rate of $8.2 \%$ for vaginal breech delivery is greater than that previously reported in a meta-analysis by Cheng and Hannah [14].

Our study sustains the general opinion that nulliparous women are at greater risk than parous women in vaginal breech delivery. In those who delivered vaginally, the neonatal mortality rate was higher in nulliparous women compared with that in parous women. This is in agreement Diro et al. [19]. It suggests that the firmer tissues of primigravidas present greater hazards of trauma and asphyxia to the fetus. It is important to inform nulliparous patients who refuse elective caesarean section and undergoing a trial breech vaginal delivery that morbidity and mortality seems to be increased in women in their first pregnancy. The neonatal mortality following vaginal breech delivery increased when fetal weight was $3500-4000 \mathrm{~g}$. This is in agreement to that of Jones et al. [23]. This is explained that macrocosmic baby is more liable to birth trauma and asphyxia and such infants should be delivered by caesarean section to avoid these adverse perinatal outcomes.

In conclusion, vaginal breech delivery is associated with significantly increase in perinatal morbidity and mortality (more evident in nulliparous women and in infants with expected birth weight 3500-4000 g), when compared with caesarean breech delivery. Caesarean section for singleton term breech is recommended as a mode of delivery in all nulliparas and for those infants with expected birth weight $3500-4000 \mathrm{~g}$.

\section{References}

1. Gilbert WM et al. Vaginal versus cesarean delivery for breech presentation in California: a population-based study. Obstetrics and gynecology, 2003, 102:911-7.

2. Sanchez-Ramos L et al. Route of breech delivery and maternal and neonatal outcomes. International journal of gynaecology and obstetrics, 2001, 73:7-14.

3. Irion $\mathrm{O}$ et al. Planned vaginal delivery versus elective caesarean section: a study of 705 singleton term breech presentations. British journal of obstetrics and gynaecology, 1998, 105:710-7.

4. Thorpe-Beeston JG, Banfield PJ, Saunders NJ. Outcome of breech delivery at term. British medical journal, 1992, 305:746-7.

5. Roman J, Bakos O, Cnattingius S. Pregnancy outcomes by mode of delivery among term breech births: Swedish experience 1987-1993. Obstetrics and gynecology, 1998, 92:945-50.

6. Confino $\mathrm{E}$ et al. The breech dilemma: a review. Obstetrics and gynecology, 1985, 40:330-7.

7. Hickok DE et al. The frequency of breech presentation by gestational age at birth: a large population-based study. American journal of obstetrics and gynecology, 1992, 166:851-6.
8. Collea JV et al. The randomized management of term frank breech presentation, a study of 208 cases. American journal of obstetrics and gynecology, 1980, 137:235-44.

9. Gimovsky ML et al. Randomized management of the nonfrank breech presentation at term: a preliminary report. American journal of obstetrics and gynecology, 1983, 146:34-40.

10. Hannah ME et al. Planned caesarean section versus planned vaginal birth for breech presentation at term: a randomised multicentre trial. Term Breech Trial Collaborative Group. Lancet, 2000, 356:1375-83.

11. Mode ofterm singleton breech delivery. Washington DC, American College of Obstetricians and Gynecologists, 2001 (ACOG Committee Opinion No. 265).

12. Hauth JC, Cunningham FG. Vaginal breech delivery is still justified. Obstetrics and gynecology, 2002, 99:1115-6.

13. Stoll BJ, Kleigman RM. The fetus and the neonatal infant. In: Behrman RE et al., eds. Nelson textbook of pediatrics. Philadelphia,WB Saunders, 2000:463-4.

14. Cheng M, Hannah M. Breech delivery at term: a critical review of the literature. Obstetrics and gynecology, 1993, 82:605-18. 
15. Bingham $\mathrm{P}$, Lilford RJ. The management of the selected term breech presentation: assessment of the risks of selected vaginal delivery versus cesarean section for all cases. Obstetrics and gynecology, 1987, 69:965-8.

16. Krebs L, Langhoff-Roos J, Weber T. Breech at term: mode of delivery? A register-based study. Acta obstetricia et gynecologica scandinavica, 1995, 74:702-6.

17. Gifford DS et al. A meta-analysis of 1995 infant outcomes after breech delivery. Obstetrics and gynecology, 1995, 85:1047-54.

18. Kiely JL et al. Mode of delivery and neonatal death in 17587 infants presenting by the breech. British journal of obstetrics and gynaecology, 1991, 98:898-904.

19. Diro $M$ et al. Singleton term breech deliveries in nulliparous and multiparous women: a 5-year experience at The University of Miami/Jackson Memorial Hospital. Discussion. American journal of obstetrics and gynecology, 1999, 8(2):247-52.

20. Doyle NM et al. Outcomes of term vaginal breech delivery. American journal of perinatology, 2005, 22(6):325-8.

21. Koo MR, Dekker GA, van Geijn HP. Perinatal outcome of singleton term breech deliveries. European journal of obstetrics and gynecology and reproductive biology, 1998, 78(1):19-24.

22. Gimovsky ML, Paul RH. Singleton breech presentation in labor: experience in 1980. American journal of obstetric and gynecology, 1982, 143:733-9.

23. Jones WR et al. Breech presentation. In: Studd G eds. Progress in obstetrics and gynecology. Volume 2. London, Churchill Livingstone, 1982:78-82.

\section{Monitoring emergency obstetric care}

Monitoring emergency obstetric care is an update of an earlier publication on monitoring the availability and use of obstetric services, issued by UNICEF, WHO and UNFPA in 1997. The indicators defined within the publication have been used by ministries of health, international agencies and programme managers in over 50 countries around the world. This revision incorporates changes based on monitoring and assessment conducted worldwide and the emerging evidence on the topic over the years, and has been agreed by an international panel of experts. It includes two new indicators and an additional signal function, with updated evidence and new resources.

This handbook aims to describe the indicators and to give guidance on conducting studies to people working in the field. It includes a list of life-saving services, or signal functions, that define a health facility with regard to its capacity to treat obstetric emergencies. The emphasis is on actual rather than theoretical functioning. The emergency obstetric care indicators described in this handbook can be used to measure progress in a programmatic continuum: from the availability of and access to emergency obstetric care to the use and quality of those services. 